\title{
CONDICIONAMENTO SÓCIO-CULTURAL DAS ORIGENS DO MOVIMENTO UNIVERSITÁRIO EUROPEU: A SINGULARIDADE DO CASO PORTUGUÊS (VII).
}

(Continuação) .

\begin{abstract}
ALDO JANOTTI
Do Departamento de História da Faculdade de Filosofia, Letras e Ciências Humanas da Universidade de São Paulo.
\end{abstract}

CAPITULO II .

HOUVE CONDICOEES PARA O NASCIMENTO DA UNIVERSIDADE PORTUGUESA?

B). - O ARCAISMO CULTURAL.

Também em Portugal, a exemplo do que aconteceu aos demais países da Europa,

"o sacerdote foi sociològicamente o representante do saber" (321).

Procedentes, por consequiência, quer a opinião de Herculano, quando afirmava que os prelados portuguêses e outros membros influentes da cleresia daquela época - refere-se ao tempo de Sancho II -.. eram em geral os homens mais cultos do reino (322), quer a opinião de Fortunato de Almeida quando dizia, louvando-se também em Herculano, que

(321). - Joaquim de Carvalho, Estudos sôbre a Cultura Portuguêsa do século XVI, Coimbra, Por Ordem da Universidade, 1947, v. I, p. 2.

(322). - História de Portugal, v. IV, p. 259. 
"foi o clero, desde o princípio da monarquia, a classe mais culta da nação" (323);

não obstante acreditemos que o clero português não tivesse sido pròpriamente a classe mais culta da nação (o que, lògicamente, implicaria em aceitar a existência de outras classes também cultas, embora com menos grau de cultura do que a clerical), e sim que, como escreve Saraiva, ter sido o clero

$$
\text { "a única classe com alguma instrução" (324). }
$$

Assim, nada mais natural que, nessas condições, tivesse o clero português o monopólio das letras (325) e, portanto, também do ensino (326) pois, até

"ao tempo de D. Denis não houve em Portugal outras escolas além das eclesiásticas" (327).

(323). - História da Igreja em Portugal, Coimbra, Editor Fortunato de Almeida, 1910, v. I, p. 493.

(324). - Op. cit., v. I, p. 47.

(325). - Fortunato de Almeida, op. cit., v. I, p. 493.

(326) . - "Ainda outras razões, completando estas, provam que o ensino não era para seculares. Carreiras civis, quase que as não havia; a estrada eclesiástica era a única verdadeiramente larga e desassombrada. Por ela é que tomavam os que sentiam em si o impulso do talento e a vocação do trabalho intelectual. A carreira da igreja atraia os pensadores; e só a igreja, só os mosteiros se iam opulentando com as magníficas livrarias. O clero era o primciro braço da representação nacional; os eclesiásticos subiam a priores, abades, gerais, bispos, arcebispos, e até a embaixadores. As primeiras obras que narraram os feitos gloriosos dos portuguêses foram cometidas por D. Afonso Henriques a dois eclesiásticos, sucessivamente, e os compêndios vinham de eclesiásticos também. Eram êles não só os capelães nos palácios dos nobres, mas os que se gosavam do título de letrados, e por letrado não se entendia ainda a profissão de advocacia, mas o homem de letras, o sabedor. Eram os eclesiásticos que tinham "a perícia de escrever", e êles sós, 'os notários de todos os documentos, mesmo daquêles que envolviam utilidade sua.

$O$ conjunto de todos os fatos que temos exposto à consideração do leitor prova que era exclusivamente eclesiástico o espírito do ensino. Os seculares que, em geral, concorriam às escolas monásticas. levados pela influência do poder que os instruia, e tendo na carreira clerical a única para que a instrução verdadeiramente habilitava, filiavam-se nas ordens; e aquêles que não se queriam sujeitar às ordens, iam pedir nos países estrangeiros a cultura do espírito às universidades que já então floresciam na Europa. Êste fato significativo corrobora a série de considerações em que nos temos firmado para entender que a instrucão do elemerto monástico, no primeiro período da monarauia, não era ministrana aos partirulares senão excepcionalmente" (Antônio da Costa. História da Instrução Ponular em Portugal desde a Fundação da Monarquia até aos nossos dias, Pôrto, Editor Antônio Figueirinhas, 1900, 2a. ed., p. 17-9) .

(327). - Fortunato de Almeida, História de Portugal, v. I, p. 493. 
O referido monopólio se constituia numa das causas do imenso poderio do clero em Portugal (328) que, acrescentado à sua enorme riqueza e à sua extraordinária ascendência moral, fazia dêle a verdadeira classe dirigente da sociedade portuguêsa, durante os séculos XII a XIV (329).

Como acontecia com todos os estados da Cristandade, Portugal, antes do aparecimento da sua Universidade, já possuia uma organização docente,

$$
\text { "embora rudimentar" (330). }
$$

São, no entanto, escassas - e assim mesmo, raramente, autenticadas por escrituras originais (331) - as notícias referentes às escolas e aos estudos (332), podendo-se explicar essa escassez documental por uma série de razões: pequeno número das escolas e pouco desenvolvimento delas, destruição de muitos dos antigos cartórios, abandôno a que os portuguêses vêm relegando o estudo dos diplomas medievais dos seus próprios arquivos (333). Dois tipos de escolas constituiam a organização docente portuguêsa antes dos fins do século XIII, a episcopal e a monástica.

As escolas episcopais devem ser estudadas em primeiro lugar. E que as mais antigas notícias de escolas portuguêsas referem-se às escolas episcopais, visto que Portugal, se comparado com a Europa, só tardiamente conheceu

(328) . - "No meio de descalabro geral da cultura desde as invasões dos bárbaros até ao século XII, só a Igreja conservara escolas nas suas sedes episcopais e nos seus mosteiros. Essas escolas destinavam-se à preparação dos quadros da própria Igreja. Resultava daí que apenas no grêmio da Igreja se encontrava o número suficiente de pessoas que soubessem ler, escrever, fazer as quatro operações, e conhecessem o latim indispensável às relações internacionais e aos documentos públicos. $\mathrm{Na}$ escrita dos scus negócios os reis e magnatas tinham de recorrer aos eclesiásticos, que formam durante muito tempo o pessoal administrativo do estado, a tal ponto que a palavra clérigo se torna sinônimo de escriba. E evidente que esta ilustração era relativa e só a profunda ignorância geral a singularizava. Há exemplos de presbíteros, cônegos e até bispos, que não sabiam ler. Mas essa não era a regra geral" (Saraiva, op. cit., v. I, p. 47).

(329). - Idem, ibidem, v. I, p. 46.

(330). - Joaquim de Carvalho, Instituiçōes de Cultura, in "História de Portugal", Ed. Monumental, v. II, p. 599.

(331). - Carolina Michäelis, Cancioneiro da Ajuda, v. II, p. 632.

(332). - Mário Brandão e Lopes de Almeida, op. cit., p. 1.

(333). - Idem, ibidem, p. 1. 


\section{$-356-$ \\ "a fase primitiva do ensino conventual" (334).}

A primeira dessas escolas episcopais é anterior ao próprio Condado Portucalense: tratava-se de uma escola fundada por volta de 1082-1086 em Coimbra por D. Paterno, bispo dessa cidade, e cuja finalidade era a de educar e instruir os jovens que se destinavam à carreira eclesiástica (335). E muito embora sôbre a organização e ensino dessa escola episcopal nada se saiba, acha Mário Brandão, o excelente historiador da vida escolar portuguêsa, que

"não será muito ousado conjeturar que devem ter sido similares aos das 'escolas catedralícias de além dos Pirineus" (336).

No século XII surgia a escola episcopal de Braga, estabelecida por São Geraldo e que cuidava de ministrar o ensino da doutrina canônica ao clero bracarense e aos párocos de outras freguesias (337). A respeito dessa escola

(334). - Saraiva, op. cit., v. I, p. 84.

(335). - O seguinte documento, datado de 13 de abril de 1086 e pela primeira vez publicado por Fr. Antônio Brandão, Monarchia Lusitana, v. III, liv. $8^{\circ}$, cap. 50, fol. 13; e Apêndice, Escritura III, atesta a existência dessa escola: "Despois o sobredito Rey (entende D. Fernando) se foy a Santiago a fazer oração, e achou D. Patrino Bispo que viéra ter com elle por mandado do Rey de Çaragoça. Ao qual Bispo naquelle tempo estava encarregado o governo da Igreja de Tortosa, mas por causa da guerra dos Mouros o não podia exercitar. E rogando-lhe o sobredito Rey com o Conde Sesnando, que se viesse morar a Coimbra, elle prometendo de vir, o não fêz em tempo deste Rey, o qual faleceu dentro de poucos dias, e possue o descanço eterno. Entrou ElRey D. Affonso no reinado de seu pay, o qual amou muito o Conde Sesnando sobredito, e lhe confirmou tudo que seu pay lhe havia dado, acrecentando algumas cousas. Despois o sobredito Bispo com recado delRey, e do Consul se veyo a Coimbra, e tomou posse de todo o bispado, e de sua diocese: e.juntamente com o Conde dêo ordem a hum seminario de moços na propria Sé episcopal, e Igreja de Santa Maria da mesma cidade, a estes doutrinou, e foy dispondo para receberem o gráo do presbyterio, quiz que vivêssem em communidade segundo a regra de Santo Agostinho. E approvando depois o mesmo Bispo e o Consul seo procedimento, e boa ordem com que viviam, e cuidado que tinham de fundar sua casa, the fizéram doação do mesmo lugar em que moravam, e prometêram que d'entre elles se escolheria o que os havia de governar, e não seria estranho, ficando comtudo á obediencia do Bispo, como era de razão que o fôsse" (apud José Silvestre Ribeiro, História dos Estabelecimentos Científicos, Literários e Artísticos de Portugal nos Sucessivos Reinados da Monarquia, Lisboa, Tipografia da Academia Real das Ciêrcias, 1871, v. I, p. 8.

(336). - Op. cit., p. 2 .

(337). - "... Clericos quos ibi reperit de ordine ecclesiastico perfecte edocuit, bonis didavit, alios, quos dignos et idoneos cognovit, illis aggregavit, et ita pulchrum et optimum conventum in Ecclesia instituit", (Vita Sancti Geraldi, in Portugaliae Monumenta Historica, Scriptores, p. 54, § 5); “... Presbyteros per parochias constitutos de doctrina canonica diligenter instruebat...". (Idem, ibidem, p. 54, $\$ 7$ ). 
"Henrique Denifle, admirável conhecedor dos arquivos do Vaticano, escreveu, citando documentos, que nenhuma outra escola catedralícia portuguêsa teria sido tão famosa como a de Braga" (338).

Em Lisboa parece que também existiu uma escola-catedral, pois Santo Antônio ali recebeu a sua primeira instrução religiosa (339). Assim, pelo que atestam os documentos. Portugal teve apenas três escolas episcopais, Coimbra, Braga e Lisboa, número insignificante, principalmente, pelo fato de não estar em proporção com o número (9) das sedes episcopais que compreendiam a administração religiosa do reino. Acreditam, no entanto, autores portuguêses, que o ensino episcopal não tenha se constituido no monopólio apenas dessas três referidas cidades, pois

"muito embora da sua existência não tenha ficado resto nos documentos" (340).

é de se pressupor que cada sé tivesse tido a sua escola episcopal (341). Para completar, deve ser citada a escola capitular de Guimarães, intimamente aparentada com as escolas episcopais (342), fundada no comêço do século XIII pelo legado pontifício João de Abbeville que, pelos estatutos outorgados em 1229, atribuiu-lhe a obrigação de manter um mestre de gramática (343). Como acreditam ainda autores portuguêses (344) que, ao lado do ensino ministrado nas escolas ca-

(338). - Mário Brandão e Lopes de Almeida, op. cit., p. 3.

(339). - Idem, ibidem, p. 3.

(340). - Idem, ibidem, p. 3.

(341). - Saraiva, op. cit., v. I, p. 85: Joaquim de Carvalho, Instituições de Cultura, in "História de Portugal", Ed. Monumental, v. II, p. 600 e História da Literatura Portuguêsa Ilustrada, v. I, p. 55; Mário Brandão e Lopes de Almeida, op. cit., p. 3-4; Fortunato de Almeida, História da lgreja em Portugal, v. I, p. 489.

(342). - Joaquim de Carvalho, Instituições de Cultura, in "História de Portugal", Ed. Monumental, v. II, p. 600 .

(343). - "Districte precipimus quodin vestra ecclesia semper sit $u\urcorner u s$ magister qui studium regat in gramatica et eidem magistro quandiu regerit unam prebendam integram asignamus" (Vimaranis Monumenta Historica. v. II, p. 201, apud Joaquim de Carvalho, op. cit., in "História de Portugal", Ed. Monumental. v. II. p. 600) .

(344). - Fr. Joaquim de Santa Rosa Viterbo, Elucidário das Palavras, Termos e Frases que em Portugal antigamente se usaram e que hoje regularmente se ignoram, Lisboa, A. J. Fernandes Lopes, 1865, vb. Clérigo, p. 197; Joaquim de Carvalho, op. cit., in "História de Portugal", Ed. Monumental, v. II, p. 600 e História da Literatura Portuguêsa Ilustrada, v. I, p. 55; Mário Brandão e Lopes de Almeida, op. cit., p. 9. 
tedrais - ensino que tinha um caráter secundário e que adquiria caráter superior no caso da teologia e da medicina,

"se de fato esta ciência foi professada em aulas portuguêsas anteriormente à fundação da Universidade" (345) -

deva ter existido um outro, de caráter elementar, ministrado por rudimentares escolas paroquiais,

"pois só assim se pode explicar a existência dos mózinhos" (346), ou monginhos, "crianças que serviam de "meninos de côro" e a quem os párocos ensinavam a doutrina e primeiras letras" (347).

As escolas monásticas completavam a organização docente da Idade Média portuguêsa pré-universitária. Dos mosteiros portuguêses destacaram-se, dentre os demais, o de Santa Cruz de Coimbra, da ordem de Santo Agostinho e o de Santa Maria de Alcobaça, da ordem dos cistercienses que, no dizer de Herculano, veio a ser o mais célebre de Portugal (348). Em ambos existiram escolas,

"centros de estudos regulares, que se mantiveram até à aurora da Renascença" (349).

A escola de Santa Cruz era uma escola interna, isto é, reservada aos noviços e aos monges (350); suas primeiras aulas remontariam, pelo menos, aos inícios do século XIII (351);

"não raras vêzes -se mandaram ao estrageiro alguns cônegos regrantes estudar as ciências que no reino se não ensinavam" (352);

(345) . - Mário Brandão e Lopes de Almeida, op. cit., p. 9.

(346). - Joaquim de Carvalho, op. cit., in "História da Literatura Portuguêsa Ilustrada. v. I. p. 55 .

(347). - Mário Brandão e Lopes de Almeida, op. cit., p. 9.

(348). - Op. cit, , v. IIJ, p. 61 .

(349). - Joaquim de Carvalho, op. cit., in "História da Literatura Portuguêsa Ilustrada", v. I, p. 57.

(350) . - Idem, op. cit., in "História de Portugal", Ed. Monumental, v. II, p. 600 .

(351). - Mário Brandão e Lopes de Almeida, op. cit., p. 5.

(352) . - Mota Veiga, Esbôço Histórico-Literário da Faculdade de Teologia da Universidade de Coimbra, Coimbra, Imprensa da Universidade, 1872, p. 14 . 
na época em que Santo Antônio lá estudou havia professôres famosos (353). Em Alcobaça, a dar-se crédito a Fr. Manuel dos Santos, havia desde a fundação do mosteiro (1153), uma "leitura" ou cadeira de teologia (354); primitivamente era uma escola interna mas, com a reforma do abade Fr. Estêvão Martins tornou-se externa (355): é que, e logo mais teremos a oportunidade de aprofundar o estudo da questão, em 1269 o referido abade determinou que no mosteiro houvesse pèrpetuamente aulas de teologia, lógica e gramática, destinadas não apenas aos monges, mas também, a todos que desejassem adquirir

"a incomparável riqueza dz sabedoria" (356).

Essas eram as escolas que constituiam a realidade pedagógica portuguêsa antes da fundação da Universidade. Na opinião de Mário Brandão não passaram de simples

\begin{abstract}
"aulas destinadas, principalmente, ao ensino dos membros dos institutos religiosos que os criarão, possuindo um reduzidíssimo corpo docente, talvez na maioria dos casos um único professor, governadas pelas autoridades eclesiásticas e monacais e não regidas pela livre deliberação dos sẹus mestres e escolares que não se encontravam ainda congregados em corporações autônomas e detentoras de sêlo privativo e de personalidade jurídica, sem, ao que parece, os seus alunos poderem aspirar ao ius ubique docendi, a tais escolas faltavam as características que distinguem as universidades, essas criações tão típicas do gênio medieval" (357).
\end{abstract}

Seria cometer, no entanto, terrível e elementar engano, se acreditássemos, em razão do que acima acabamos de expor — ou seja, monopólio da instrução pelo clero e existência das escolas episcopais e monásticas - que a pedagogia medieval portuguêsa estivesse efetivamente integrada no quadro geral da pedagogia européia. Apenas na aparência ou na forma é que se poderia registrar essa integração. Nunca, porém, naquilo que mais importa, isto é: do dinamismo tão

(353) . - Mário Brandão e Lopes de Almeida, op . cit., p. 6. p. 87 .

(354). - Alcobaça Ilustrada, 1710, p. 100, apud Saraiva, op. cit., v. I,

(355) . - Joaquim de Carvalho, op. cii., in "História de Portugal", Ed. Monumental, v. II, p. 600.

(356). - Fr. Manuel dos Santos, Alcobaça Ilustrada, p. 101, apud Saraiva, op. cit., v. I, p. 89.

(357). - Op. cit., p. 10-11. 
característico da pedagogia da Europa e que era responsável por uma constante renovação do seu ensino. Foi, precisamente, devido ao fato da pedagogia medieval portuguêsa não ter contado com condições sócio-culturais, para acompanhar o dinamismo da pedagogia européia que ela se tornou anacrônica. Como se manifestava o anacronismo pedagógico português? Da maneira a mais nítida e, ao mesmo tempo, a mais singela que nos seria dado supor: enquanto na Europa as escolas episcopais - escolas eminentemente urbanas - instalavam, num processo pedagógico dinâmico, a sua supremacia sôbre as escolas monásticas, renovando em conseqüência o ensino, como já tivemos oportunidade de ver, e, ao mesmo tempo, revolucionando-o, pois delas, isto é, das escolas episcopais, as Universidades irão ser o seu natural desenvolvimento, em Portugal, era, precisamente, o contrário que acontecia. Numa demonstração inequívoca de inércia cultural e de arcaismo pedagógico as escolas monásticas em Portugal - do tipo primitivo, deve-se salientar - nunca foram superadas pelas escolas episcopais, pois conseguiram aquelas, as escolas monásticas, manter a sua supremacia pedagógica no decorrer dos séculos XII, XIII e XIV, época em que, na Europa, a supremacia da escola monástica não só já tinha sido transferida para a escola episcopal, como também a Universidade já tinha imposto a sua supremacia sôbre esta última. Autores vários têm feito referências à peculiar situação anacrônica da pedagogia medieval portuguêsa, comparativamente à européia. E assim que se expressa, por exemplo, Antônio Saraiva:

"Na época em que se constituia a monarquia portuguêsa, os mosteiros tinham perdido uma grande parte do seu papel preponderante na vida intelectual da Cristandade. Êsse papel fôra máximo nos séculos VIII, IX e $\mathrm{X}$, quando ali se refugiavam os homens sabedores e o trabalho intelectual, como em ilhas emergindo de um dilúvio de barbarização. A própria Igreja secular, cujos membros tendiam a participar da barbaria e ignorância geral, recrutava nos conventos grande parte dos seus dirigentes. Mas desde o século XI, com o florescimento das escolas episcopais, a cultura emigra dos mosteiros para estas escolas, secularizando-se em certa medida; e desde os fins do século XII as Universidades sucedem às escolas episcopais e a cultura tende a emancipar-se da Igreja. Quando se fundam, ho século XIII, as ordens mendicantes, dá-se uma renovação da atividade intelectual das ordens monásticas. Os dominicanos e franciscanos têm as suas escolas, e os seus mestres prticipam, ativamente, da vida universitária. São Tomás de Aquino e Alberto Magno, dominicanos; São Boaventura e Roger Bacon, franciscanos, documentam esta renascença da cultura monástica. Mas a época do monopólio da cultura pe- 
los conventos tinha, definitivamente, passado e com ela a velha instituição do mosteiro e do saber, no meio de uma sociedade completamente iletrada.

Ora, ao contrário do que sucedia para lá dos Pirincus, em Portugal, a cultura monástica do tipo primitivo conserva tôda a sua importância nos séculos XII, XIII e XIV; das escolas episcopais há, como vimos, escassíssimas notícias e da Universidade não consta que fôsse um foco assinalável de cultura antes do sécuḷo XVI. E êste um dos aspectos arcaizantes da cultura portuguêsa anterior ao século XV: o predomínio da cultura monástica quando a sua época tinha passado no resto do mundo cristão" (358) (grifo nosso).

Mário Brandão, por sua vez, afirma:

"Não foram as escolas episcopais as únicas que se estabeleceram em Portugal, pois também os grandes mosteiros tiveram anexos institutos semelhantes. E estamos convencidos que, ao contrário do que acontecia em França, onde no período que precedeu o advento das Universidades as escolas monacais perderam muito da sua importância a favor das catedralícias, no nosso país foram as primeiras que mais se desenvolveram antes da fundação do estudo geral dionisiano". (359).

Realmente, enquanto na Europa decaiam os mosterios (360), como centros intelectuais e escolares em favor das escolas episcopais, em Portugal os mosteiros de Alcobaça e de Santa Cruz eram os dois

(358). - Op. cit., v. I, p. 203-4.

(359). - Op. cit., p. 4-5.

(360). - "En Allemagne, c'est, dans les monastères, la plus profonde décadence; et en Angleterre, l'activité littéraire des chroniqueurs, au temps de Henry II, doit être rattachée beaucoup plus aux cathédrales qu'aux monastères. Mais en Italie, l'abbaye du Mont-Cassin prolonge sa magnifique prospérité du XIe siècle, avec son fameux bibliothécaire Pierre le Diacre (+ après 1140), qui écrit un catalogue $\vec{D} e$ viris illustribus de son monastère.

Cependant, comme on l'a dit, ce catalogue est une épitaphe: le Mont-Cassin ne produisit plus d'écrivains notables, et Pierre lui-même est un symptôme de son déclin. Ainsi en va-t-il dès avant la moitié du douzième siècle dans toutes les abbayes, à Liége comme au Bec ou à Cluny, lá même où nous recueillions encore quelques beaux fruits" (Paré, Brunet, Tremblay, op. cit., p. 46-7). E sôbre a educação de Luis VII de França assim se referem os mesmos autores, op . cit., p. 47, in nota: "Tandis que le roi Louis le Gros avait reçu l'instruction des moines de Saint-Denys, son fils Louis VII (né en 1119) fut formé aux écoles de Paris. Ce fait royal est significatif". 
focos literários mais notáveis (361). As escolas monásticas portuguêsas - particularmente, as dos dois mosteiros acima citados - eram de um tipo de organização pedagógica mais complexa (362); nelas é

"que o ensino se ministrou mais largamente, não só quanto às disciplinas eclesiásticas, mas ainda na esfera de outras ciências" (363);

e num nível superior ao das escolas episcopais (364). Os monges dominavam o ensino, e a tal ponto, acredita Antônio da Costa, que nos primeiros tempos da monarquia êle era privativo dos mosteiros (365). Não causa estranheza, assim, o fato dos clérigos regulares terem sido mais instruidos do que os clérigos seculares (366).

Revelava-se ainda a supremacia da escola monástica sôbre a escola episcopal - nôvo elemento do arcaismo pedagógico português - através da superioridade dos professôres regulares sôbre os professôres seculares. Os professôres de mais fama de que temos notícias eram os encontrados nas escolas monásticas: era o caso de conhecidos mestres do século XIII como D. João, notável teólogo (367), doutorado pela Universidade de Paris (368); de p. 499 .

(361). - Fortunato de Almeidá, História da Igreja em Portugal, v. I,

(362) . - Joaquim de Carvalho, op. cit., in "História da Literatura Portuguêsa Ilustrada, v. I, p. 57 .

(363). - Fortunato de Almeida, op. cit., v. I, p. 489.

(364). - Saraiva, op. cit., v. I, p. 88.

(365). - "Tentamos esboçar o estado da instrução quando D. Afonso Henriques fundou o reino de Portugal, e mostrámos que o nosso primeiro monarca reivindicava a terra lusitana sem encontrar o ensino organizado, como princípio; que mesmo as circunstâncias políticas, sociais e européias não exigiam a instrução como satisfação às necessidades públicas; que a $\mathrm{D}$. Afonso Henriques e aos seus sucessores se deveu, com a introdução do elemento monástico, o único elemento que naquelas eras podia inaugurar e sustentar o ensino, tendo pertencido ao fundador da monarquia o lançar as raizes do estudo entrelaçadas às raizes da independência; que o ensino era ministrado só pelos monges, e verdadeiramente para as classes eclesiásticas; que o ensino oficial não representou papel nenhum direto na organização da instrução nacional, sendo o ensino dos mosteiros a única feição característica da instrução no primeiro período da monarquia; e que no ponto especial da educação popular não existia ainda nenhum dos elementos que viriam a fundar a constituição do ensino" (op . cit., p. 20-1).

(366): - Fortunato de Almeida, op. cit., v. I, p. 493.

(367). - Mário Brandão e Lopes de Almeida, op. cit., p. 6.

(368). - Joaquim de Carvalho, op . cit., in "História de Portugal", Ed. Monumental, v. II, p. 600 . 
"D. Fr. Raimundo, profundissime in diversis scientiis literatus, e D. Fr. Pedro Pires, magnus in Grammatica, Logica, Medecina et in Theologia" (369);

de S. Fr. Gil, mandado por

"seu pai a estudar às escolas de Paris, para se fazer aí licenciado em medicina" (370).

Mas na evolução da pedagogia européia o que se passou foi precisamente o contrário: inicialmente destacaram-se, como grandes mestres os profesôres das escolas monásticas, caso de Fulberto, Yves de Chartres, Anselmo de Bec (371); a seguir, com a transferência da supremacia da escola monástica para a episcopal os grandes mestres que se destacam são os seculares, isto é, os professôres das escolas urbanas: é o caso - referindo-nos apenas à França e, note-se, no século XII — de Anselmo de Laon, Guilherme de Champeaux e, sobretudo, Abelardo, figura tão ìntimamente ligada às origens do movimento universitário europeu (372).

Também no que se refere ao mais poderoso de todos os instrumentos do trabalho intelectual, isto é, o livro - e, no conjunto dos livros, as bibliotecas - continuava arcaica a pedagogia medieval portuguêsa. Já vimos como, devido ao renascimento cultural que a Europa conheceu no século XII, as bibliotecas dos mosteiros, criadas e desenvolvidas por ocasião do apogeu das escolas monásticas, não esti-

(369). - Idem, ibidem, in "História de Portugal", Ed. Monumental, v. II, p. 600 .

(370) . - Fr. Diogo do Rosário, Flos sanctorum, apud nota de José Maria Rodrigues, in Denifle, $A$ Universidade de Lisboa-Coimbra, p. 21.

(371). - Este, no dizer de Rashdall, foi o último grande professor monástico (The Universities of Europe in the Middle Ages, v. I, p. 43) .

(372). - "With Abelard the great scholastic movement reaches a point at which it begins to identify itself with what we may call the university movement. Most emphatically it must be asserted that universities, even in their most rudimentary form, did not exist till at least a generation after Abelard. But Abelard inaugurated the intellectual movement out of which they eventually sprang. The method of inquiry and of teaching of which he was the originator was the method which essentially characterized the teaching of the medieval universities - a method transferred by Abelard from philosophy to theology, and afterwards (in a greater or less degree) to the whole cycle of medieval studies. Even from the point of view of external organization Abelard may in a sense be said to inaugurate the university movement" (Rashdall, op. cit., v. I, p. 43). 
veram mais em condições de acompanhar as novas necessidades da cultura, em geral, e da pedagogia, em particular, pois elas deixaram de munir-se, devidamente, das "novidades". da produção literária, como também se ressentiram do torpor do ensino que vai pasar a caracterizar aquelas escolas. A medida que vai sendo imposta a superioridade da escola episcopal sôbre a escola monástica, as bibliotecas desta vão sendo também suplantadas pelas daquela. Por fim, completando a evolução, a "hegemonia livresca", a exemplo do que se deu com a hegemonia pedagógica, é transferida para as universidades. Estas, concorrendo com o clero e fazendo com que êle perrdesse o monopólio da produção livreira, acabaram desempenhando o principal papel na laicização do livro (373). Mas em Portugal não podemos perceber a mesma evolução. Tirânicamente submetido a uma estrutura agrária arcaica, que não the permitiu usufruir dos benefícios de um renascimento urbano e não tendo conhecido, nem ao menos anacrônicamente, as influências renovadoras que o renascimento do século XII proporcionou à cultura européia, a situação livresca de Portugal não era senão o resultado da sua peculiar situação sócio-cultural. Pouco ou nada, resultante da sua pequena importância, há que se falar das bibliotecas episcopais, isto é, dos centros eminentemente urbanos: Joaquim de Carvalho limitou-se a dizer que eram

$$
\text { "modestas e de tênue projeção" (374); }
$$

Saraiva a elas nem faz referências (375). E sôbre a biblioteca da futura Universidade - e na Europa do século XIII a vida intelectual, abandonando as grandes abadias e concentrando-se nas universidades, causou uma verdadeira revolução no fábrico do livro (376) -

"nada sabemos" (377): mas se "pudéssemos fazer um juízo retrospectivo, pelos inventários feitos em 1532 e 1536, a conclusão não seria honrosa e teríamos de afirmar que o Estudo Geral de Lisboa viveu, à margem, de tôda a renovação ideológica, fossilizando-se nos velhos textos" (378).

(373). - Saraiva, $O P$. cit., v. I, p. 82.

(374). - Op. cit., in "História da Literatura Portuguêsa Ilustrada, v. I, p. 64 .

(375). - Op. cit., v. I.

(376). - Paré, Brunet, Tremblay, op. cit., p. 87, citando J. Destrez, Etudes critiques sur les oeuvres de saint Thomas d'Aquin d'après la tradition manuscrite, Paris, 1933, p. 8.

(377). - Joaquim de Carvalho, op. cit., in "História da Literatura Portuguêsa Ilustrada, v. I, p. 65 .

(378) - Idem, ibidem, in "História da Literatura Portuguêsa Ilustrada, v. I, p. 65 . 
Não causando estranheza, assim, o fato de que nas Universidades européias, e inclusive, espanholas, existiu uma clientela ou corporação de industriais do livro (escribas, iluminadores, pergaminheiros, encadernadores, estacionários) (379), cuja função era a de fabricar o livro, indispensável que se tornava êste para um ensino universitário digno, enquanto faltam notícias a respeito da existência dessa mesma corporação de livreiros junto da Universidade portuguêsa (380).

$\mathrm{Na}$ realidade, os dois grandes centros livreiros da Idade Média portuguêsa foram os mosteiros e - quando, mais tarde, se inicia a secularização da vida intelectual - os paços reais (381). Quanto às bibliotecas reais, não há que exagerar a sua importância, pelo menos até o século XV: as bibliotecas dos monarcas da primeira dinastia não eram públicas, abertas aos que tinham interêsse ou necessidade de uma consulta livresca, não realizando, assim, uma verdadeira e eficiente função cultural; pelo contrário, era um conjunto de livros que se constituia num bem pessoal de um determinado monarca,

\author{
"livremente disponível", "que nascia e desaparecia com a \\ vontade do fundador" (382),
}

destinado a satisfazer, quando era êsse, precisamente, o caso, às necessidades espirituais, exclusivamente, do seu proprietário; sòmente no século XV a biblioteca real perderá o seu caráter pessoal, para trans-

(379). - Cf. Rashdall, The Universities of Europe in the Middle Ages, v. I, p. 189-90. Era da seguinte maneira que, no século XIII, Afonso X, cognominado o Sábio, estabelecia e regulamentava o serviço dos livreiros das Universidades espanholas: "Estacionarios ha meester que haya en cada estudio general para seer complido, et que tenga en sus estaciones libros buenos, et legibles et verdaderos de texto et de glosa que los loguen los escolares para enxemplarios, para facer por ellos libros de nuevo ó para emendar los que tovieren escriptos: et tal tienda ó estacion como esta non la debe ninguno tener sin otorgamiento del rector del estudio; et el rector ante que le dé licencia para esto debe facer examinar primeramiente los libros daquel que quier tener la estacion para saber si son buenos, et legibles et verdaderos: et al que fallase que non tiene atales libros non le debe consentir que sea estacionario nin los logue á los escolares, á menos de non seer bien emendados primeramente. Otrosi debe apreciar el rector con consejo de los del estudio quánto debe rescebir el estacionario por cada quaderno que prestare á los escolares para escrebir ó para emendar sus libros: et debe otrosi rescebir buenos fiadores cél que guardará bien et lealmente todos los libros que á él fueren dados para vender, et que non fará engaño" (Las Siete Partidas, Madrí, Imprenta Real, v. II, Partida II, título XXXI, lei XI, p. 345-6) .

(380). - Saraiva, op. cit., v. I, p. 82.

(381). - Joaquim de Carvalho, op. cit., in "História de Portugal", Ed. Monumental, v. II, p. 612 .

(382). - Idem, ibidem, in "História de Portugal", Ed. Monumental, v. II, p. 614 . 
formar-se numa propriedade da Corôa, conquistando então, no dizer de Joaquim de Carvalho, uma significação inédita, altamente renovadora da cultura portuguêsa pois, menos policiada do que as livrarias monásticas, aberta a novas idéias, satisfazendo novas inquietações do espírito, ela irá assinalar uma nova fase de secularização intelectual e converter-se num centro de saber, como atestam a atividade literária da côrte de D. João I e a obra do cronista Gomes Eanes de Azurara (383). Todavia, tudo isso se deu, muito tempo após a fundação da Universidade, e o que nos interessa é a situação anterior. Possìvelmente surgiu com $\mathrm{D}$. Denis, e com aquêle caráter peculiar de patrimônio pessoal e de função cultural restrita, a primeira das bibliotecas reais (384): deve-se, no entanto, observar, em primeiro lugar, que ao certo, quanto à biblioteca do referido monarca, sabe-se que ela possuia apenas livros litúrgicos (385), embora, entre outros autores - como, por exemplo, Teófilo Braga (386) - acredite Joaquim de Carvalho ser

"fora de dúvida que a sua livraria deveria satisfazer outras inquietaçōes do espírito não exclusivamente religiosas" (387);

e, em segundo lugar, que a biblioteca de $\mathrm{D}$. Denis era uma pequena biblioteca, embora acredite, ainda, Joaquim de Carvalho que

"não deve considerar-se a escassez de documentos como sinônimo de pobreza ou de incultura" (388).

As bibliotecas monásticas, numa época em que na Europa elas já tinham sido superadas, como eficientes instrumentos de uma cultura em processo contínuo de renovação, é que dominavam a paisagem livresca portuguêsa - reflexo de um anacrônico domínio da cultura

(383). - Idem, ibidem, in "História de Portugal", Ed. Monumental, v . II, p. 614 .

(384). - "Nos testamentos de Sancho I e Afonso II não se faz referência a livros; e os 2 códices legados pela filha de Sancho I, D. Mafalda, que morreu monja professa, devem antes considerar-se como objetos eclesiásticos". (Saraiva, op. cit., v. I, p. 82).

(385). - E a única coisa que se pode concluir do seu testamento lavrado em 1321 quando, entre outros bens, legava a seu filho Afonso todos os livros "que pertencem à minha capela". (apud Joaquim de Carvalho, op. cit., in "História de Portugal", Ed. Monumental, v. II, p. 614).

(386). - História da Universidade de Coimbra nas suas Relações com a Instruções Pública Portuguesa, Lisboa, Por Ordem e na Tipografia da Academia Real das Ciências, 1892, v. I, p. 57-8. p. 614 .

(387). - Op. cit., in "História de Portugal", Ed. Monumental, v. II, (388). - Idem, ibidem, v. II, p. 614. 
pelo mosteiro (389). Tomando uma atitude otimista, acredita Joaquim de Carvalho que todos os mosteiros medievais portuguêses possuiam livraria, qualquer que fôsse a regra monástica dos seus professos (390). Já Antônio Saraiva, talvez mais prudente, acha que, contrastando com as bibliotecas relativamente copiosas dos mosteiros de Santa Cruz e de Alcobaça,

"há razões para pensar que havia outras muito pobres, e, até mosteiros onde não se copiava nem se lia" (391).

Santa Cruz e Alcobaça eram os mosteiros onde se achavam as "mais celebradas" bibliotecas da Idade Média portuguêsa (392). O espólio da biblioteca do mosteiro de Santa Cruz perdeu-se quase inteiramente (393): mas por notícias sumárias,

$$
\text { "que mal conseguem frágeis induções" (394), }
$$

pode-se afirmar que a referida livraria foi um instrumento de estudos regulares, a sede de uma pequena academia sábia (395); que

$$
\text { "organizando a primeira livraria de alcance pedagógico" }
$$
(396),

(389). - "Desde o século XII os burgueses de grosso trato e seus procuradores, os reis com o seu serviço administrativo e diplomático cada vez mais complexo, uma aristocracia com uma vida social mais luxuosa e artística, e principalmente as universidades com as suas centenas ou milhares de estudantes, tendem a criar um serviço cada vez mais amplo de cópia de livros. Os conventos perdem o monopólio da produção livreira". (Saraiva, op. cit., v. I, p. 81-2).

(390) . - Instituições de Cultura, in "História de Portugal", Ed. Monumental, v. II, p. 613.

(391). - Op. cit., v. I, p. 80.

(392). - Idem, ibidem, v. I, p. 80. Joaquim de Carvalho refere-se ainda a uma terceira biblioteca, a do mosteiro beneditino de Lorvão e da qual chegaram até nós dois códices: o Livro das Aves (1183), volucrário atribuido a Hugo de São Vítor e o chamado A pocalipse de Lorvão, cópia feita em 1189 de um comentário do Apocalipse escrito em 786 por um sacerdote asturiano (op . cit., in "História de Portugal", Ed. Monumental, v. II, p. 613).

(393) . - "Da primeira (refere-se a Santa Cruz) existe um catálogo, ao que parece incompleto, elaborado no século XVIII, que régistra 95 códices de pergaminho. Sabe-se que grande parte da primitiva biblioteca foi destruida por ordem de um dos priores do século XVIII, mas não há razão para pensar que o fosse a parte maior" (Saraiva, $o p$. cit., v. I, p. 80) .

(394) . - Joaquim de Carvalho, op . cit., in "História da Literatura Portuguêsa Ilustrađa", v. I, p. 62 .

(395) . - Idem, ibidem, in "História de Portugal", Ed. Monumental, v. II, p. 613 .

(396) . - Idem, ibidem, in "História da Literatura Portuguêsa Ilustrada", v. I, p. 62 
o mosteiro de Santa Cruz

"soube aliar aos fins religiosos os fins de cultura" (397);

que, enfim, aquela livraria

"foi a alma-mater dos estudos no centro do País" (398).

Mas a biblioteca do mosteiro de Alcobaça superava de muito a do mosteiro de Santa Cruz, constituindo-se então, coisa que não mais seria possível na Europa,

"a biblioteca nacional do Portugal medievo" (399).

Teófilo Braga chegou mesmo a afirmar que ela era

"indisputàvelmente uma das mais opulentas coleções manuscritas da Idade Média da Europa" (400).

Embora, no aspecto comparativo, talvez seja exagerada a opinião do ilustre historiador português (401), não padece dúvida de que se tratava de biblioteca imponente (402), variada e rica (403), principalmente se se levar em conta o acanhamento peculiar do ambiente cultural português. $O$ acervo mais antigo e mais importante é o constituido pela literatura religiosa (textos sagrados, literatura patrística, literatura mística): Santo Agostinho é o autor que possui o maior número de obras e de exemplares; aparecem Gregório Magno, Orígenes, São Jerônimo, Santo Ambrósio; idem São Bernardo e os "vitorinos" (Hugo de São Vítor, Ricardo de São Vítor); não faltam as glosas, catenas, dicionários bíblicos e outras obras semelhantes, cuja função

\footnotetext{
(397) . - Idem, ibidem, in "História da Literatura Portuguêsa Ilustrada", v. I, p. 62 .

(398). - Idem, ibidem, in "História de Portugal", Ed. Monumental, v. II, p. 613 .

(399) . - Idem, ibidem, in "História da Literatura Portuguêsa Ilustrada", v. I, p. 62 .

(400). - Op. cit., v. I, p. 54.

(401). - E a seguinte a opinião de Saraiva, op. cit., v. I, p. 80: "Quanto à biblioteca monástica de Alcobaça possuimos o testemunho de um monge, Fr. João Claro, que em 1520 noticiava ao rei que a livraria do mosteiro não chegava a conter 500 códices. Efetivamente o catálogo de 1775 regista 476 códices manuscritos, número certamente considerável, mas muito inferior ao das melhores bibliotecas monásticas européias da época, devendo notar-se que parte dêsses manuscritos (mais de 50) são dos século XVI, XVII e XVIII". (402). - Saraiva, op. cit., v. I, p. 208.

(403). - Joaquim de Carvalho, op. cit., in "História de Portugal", Ed. Monumental, v. II, p. 613 .
} 
era ensinar o monge a interpretar e explicar a Escritura; representando a especulação religiosa anterior ao tomismo, aparecia Santo Anselmo de Cantuária; e a Teologia estava representada por Pedro Lombardo e São Tomás de Aquino (404). Quanto à literatura profana apareciam os restos da ciência antiga que foram compilados por Santo Isidoro nas Etimologias; apareciam também Cassiodoro e Boécio; quase não há vestígios dos poetas e pensadores profanos da Antigüidade e da Idade Média; e raros eram os livros de História (405).

Todavia, o arcaismo pedagógico português não para aí; prossegue, manifestando-se, num processo cada vez mais claro e cada vez mais crescente, até conhecer uma espécie de apogeu. Esse apogeu é marcado pelo ano de 1269, quando o abade Estêvão Martins ordenou que houvesse, para sempre, no mosteiro de Alcobaça, aulas de Gramática, Lógica e Teologia, destinadas tanto aos monges alcobacenses quanto aos

"de fora que se quisessem aproveitar".

Vejamos antes de mais nada de que maneira o cronista Fr. Manuel dos Santos se refere à questão bem como a escritura pública de fundação da referida escola:

"Padecia por êste mesmo tempo o Reino de Portugal a grande falta de letras públicas, que teve desde seu princípio até os felizes anos do Rei Dom Denis: porque êste Príncipe foi quem ordenou de novo em Lisboa a nossa Universidade: eram perniciosas as consequiências daquela falta, assim como na administração da justiça, como no govêrno das Igrejas; e sobretudo porque viviam necessitados os portuguêses a irem mendigar letras a reinos estranhos, ou a chamarem a si estrangeiros para os haverem de governar. Considerava, e praticava com seus Monges o Abade Dom Fr. Estêvão estas inconveniências com um ânimo zeloso do bem comum; e quando já se desenganou de que não veria em seus dias uma obra de tanta utilidade para o Reino, qual seria uma Academia pública, se resolveu em servir a sua pátria naquele melhor modo, que lhe era factivel, e ser ou exemplo, ou confusão aos que governavam o Reino. Já desde a fundação do Mosteiro se lia em Alcobaça Teologia aos Monges; agora o Abade acrescentou as lições, e as fêz públicas para também os de fora que se quisessem aproveitar. Ordenou que se lesse para

(404). - Saraiva, op. cit., v. I, p: 232-3.

(405). - Idem, ibidem, v. I, p. 233. 
sempre na Casa Gramática, Lógica e Teologia; e para a sustentação dos Mestres, e perpétua conservação das liçōes aplicou as rendas da Vila de Alvorninha, com outras fazendas mais no território da Vila de Óbidos; e de tudo êle, e os Monges outorgaram uma escritura pública, a qual principia assim:

"Em nome de Deus, Amém. Porque em tôdas as criaturas está posta uma luz natural de inteligência, pela qual se nos facilita o caminho de podernos vir no conhecimento do Criador, já deposta a obscuridade da primeira ignorância: todos os homens (se pudesse ser cômodamente) houveram de procurar com diligência $\circ$ benefício da sabedoria. Por esta razão Nós Estêvão Abade, e o nosso Convento de Alcobaça fazemos saber aos que a presente virem, em como do nosso comum consentimento ordenamos à honra de Deus, e da bemaventurada sempre Virgem sna Mãe, e de todos os Santos, e para comum utilidade de nossos Monges, e de todos os mais que desejarem adquirir a incomparável riqueza da sabedoria, instituimos em nosso Mosteiro um contínuo, e perpétuo estudo de letras; para conservação do qual, e para sustento dos Mestres aplicamos tôdas as rendas, etc.". Leu-se a primeira lição pública em onze de Janeiro do ano de 1269 , sendo Rei de Portugal Dom Afonso terceiro: e quando ao depois o Rei D. Denis instituiu a Universidade, foi consequiência necessária da mesma instituição que se esfriasse em Alcobaça a freqüência dos estudantes; porém não em modo que se esquecessem de todo os estudos, e ainda hoje se conservam as relíquias da instituição presente; porque ainda se lêem duas cadeiras públicas, uma de Gramática, outra de casos de consciência; para glória imortal do Real Mosteiro de Alcobaça, e para eterno louvor do Abade Dom Frei Estêvão autor dos primeiros estudos públicos, que houve neste Reino, e a cuja imitação se criou ao depois a Real Universidade de Coimbra" (406).

Segundo Saraiva, o que há de mais notável, na fundação escolar de Fr. Estêvão Martins é o fato dela

"destinar-se não apenas ao ensino dos monges, mas também ao dos leigos" (407).

E Rashdall, impressionado por êsse mesmo fato, entreviu nela possìvelmente com razão afirma Saraiva (408) - a

(406). - Alcobaça Ilustrada, Coimbra, 1710, p. 100-2.

(407). - Op. cit., v. I, p. 89.

(408). - Idem, v. I, p. 89. 


\begin{abstract}
"interessante - e talvez única - tentativa de estabelecer algo parecido com um studium generale em conexão com um mosteiro" (409).
\end{abstract}

Caberia assim a Portugal a primazia de pretender a criação de uma Universidade monástica. Universidade monástica que nos mostraria, resultante de uma estrutura sócio-econômico-cultural atrasada, o característico arcaismo pedagógico português em tôda a sua plenitude, pois as Universidades européias surgiram como consequiência do desenvolvimento das escolas episcopais, escolas estas que, na sua predominância sôbre as monásticas, demonstraram a sua capacidade dinâmica de adaptação a um mundo sob todos os aspectos nôvo, qual seja o que emergiu com o renascimento das cidades. Universidade monástica ainda, que, ao invés de revelar pelo menos a fôrça, posto que arcaica, da cultura monástica, indisputàvelmente a que predominava no contexto geral da cultura portuguêsa da Idade Média, revelava sim, antes de mais nada, sua fraqueza e sua penúria: afinal, o que se ordenava fôsse estudado na "pretendida Universidade monástica"?: Gramática, Lógica e Teologia; isto é, duas disciplinas (Gramática e Lógica) de uma forma elementar de ensino, o Trivium e uma única (Teologia) de caráter superior. Mas seria quanto muito uma caricatura de Universidade, nunca uma verdadeira Universidade. Além disso, a Gramática já era ensinada, sendo mesmo a mais difundida de tôdas as disciplinas (410). A Teologia - que não será ensinada na futura Universidade portuguêsa - a dar-se crédito ao cronista que acabamos de fazer referência, era ensinada em Alcobaça desde a fundação do mosteiro (411); e temos notícia de que era ensinada também no mosteiro de Santa Cruz (412). Do ensino da Lógica, porém, não há notícias. Embora não acreditemos que tivesse Fr. Estêvão Martins a intenção de fundar uma Universidade monástica - e repetimos, seria uma tentativa única na história das Universidades européias, pois na Europa de há muito que já estava ultrapassado o mosteiro como foco de cultura —, não podemos, entretanto, deixar de observar que a Universidade portuguêsa surgiu num tempo em que Portugal ainda estava dominado por aquela forma arcaica de cultura, ou seja a monástica. Talvez sob êsse aspecto se possa dizer que a Universidade portuguêsa foi uma Universidade monástica: não funda-

(409). - The Universities of Europe in the Middle Ages, v. II, p. 109, in nota.

(410) . - Joaquim de Carvalho, op. cit., in "História de Portugal", Ed.

Monumental, v. II, p. 601 .

(411). -Alcobaça llustrada, p. 100.

(412). - Cf. Saraiva, op. cit., v. I, p. 87. 
da por monges, mas nascida sob a égide da supremacia da cultura monástica.

$\mathrm{Na}$ realidade, estamos diante de uma manifestação, a mais enfática, do arcaismo pedagógico português, e a solução do problema, acreditamos, é mais simples do que se possa imaginar. O que pretendeu Fr. Estêvāo Martins, em 1269, não foi criar uma Universidade monástica: e, sim, apenas transformar a primitiva escola que existia no mosteiro de schola interior claustri, que era reservada aos monges alcobacenses, numa schola exterior, isto é, também aberta aos seculares. Lògicamente, não interessa a questão, se Fr. Estêvão Martins foi ou não, bem sucedido na sua tentativa de criar uma escola nova em Alcobaça. Questão, aliás, controvertida: Rashdall, levado pela sua idéia de Universidade monástica, achava que não, como conseqüência do fato do abade alcobacense ser encontrado em 1288, como líder dentre os eclesiásticos que solicitaram a D. Denis a criação de um studium generale em Lisboa (413). Fr. Manuel dos Santos achava que sim, tendo, portanto, funcionado a escola que, todavia, decaiu após a fundação da Universidade (414). Joaquim de Carvalho também acreditava na

\section{"persistência da escola pública, fundada por D. Fr. Estêvão Martins" (415).}

E não encontramos motivos para acreditar de modo diferente ao dos autores portuguêses. O que interessa sim, sobretudo, é a data tentativa malograda ou realizada, não importa - em que surgiu a primeira escola pública portuguêsa: 1269 . É ela que nos proporciona tôda a perspectiva necessária para compreender mais essa manifestação do arcaismo pedagógico português.

Efetivamente, na Europa - vimos já, apoiados em De Wulf desde o comêco do século IX, estabeleceram-se nos mais famosos mosteiros, ao lado das escolas internas, destinadas à formação do monge, as escolas externas,

"abertas a todos aquêles que sentiam a necessidade ou a vocação da ciência" (416).

\footnotetext{
(413). - $O p$. cit., v. II. p. 109, in nota.

(414). - Op. cit., p. 102. p. 613 .

(415). - Op. cit., in "História de Portugal", Ed. Monumental, v. II,

(416). - Montalembert, Précis d"Histoire Monastique: Des origines à la
} fin du XIe siècle, Paris, Librairie Philosophique J. Vrin, 1934, p. 128. 
E pensando nessas escolas externas que somos tentados a acreditar que não é totalmente feliz Saraiva quando afirma que o ensino nas escolas monásticas

\footnotetext{
"tinha porém um restrito raio de ação, porque abrangia quase exclusivamente os futuros monges, os "oblatos" que os pais destinavam desde crianças à vida monacal" (417).
}

Parece ser tendência das autoridades no assunto, quer antigas quer modernas, de alargar, ao invés de restringir, o raio pedagógico de ação das escolas monásticas (418). Importante é acompanhar as diferentes etapas da evolução dessas escolas externas européias, a fim de melhor compreendermos a significação da sua congênere portuguêsa. A partir do século XII, como conseqüência de transformações de ordem econômica e social, dá-se a transferência da supremacia da escola monástica, para a escola episcopal: os

"mosteiros foram abandonados ao seu isoladamento rural" (419)

e agora é nas cidades que as elites encontram a satisfação das suas necessidades culturais (420); tanto mais que o desenvolvimento da vida intelectual ratificava êsse isolamento exterior:

(417). - Op. cit., v. I, p. 83-4.

(418). - Assim se pronunciava Montalembert: "Quant aux grandes éco-

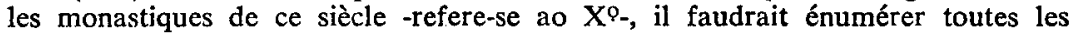
abbayes principales dont nous avons rappelé les fondateurs; car on n'en trouve point qui n'avaient été dès lors un centre d'études valides, aussi frequenté par les enfants des serfs et des pauvres, que par ceux de la noblesse et des hommes libres. Dès le milieu du siècle précédent, un concile de Mayence avait ordonné que tous les enfants seraient conduits, soit aux écoles des monastères, soit à celles de leurs prêtres, pour y apprendre les rudiments de la foi et l'oraison dominicale dans leur langue maternelle. Ce n'était donc pas seulemient aux futurs habitants du cloître, mais à tous les fils des chrétiens, que les moines ouvraient leurs portes et accordaient l'hospitalité de l'instruction". (Op. cit., p. 129-30). E, nos dias que correm, assim se expressa J. Décarreaux: "L'observance bénédictine, en imposant chaque jour un temps de lecture sacrée, requiert un certain degré d'instruction. Ceux qui ne l'apportent pas du dehors la reçoivent au-dedans. Ce sont d'abord les enfants présentés par leurs parents à l'abbé pour qu'il en fasse de moines. Le monastère bénédictin a donc, dans ses murs, une école où des maîtres enseignent le rudiment aux oblats. En bien des cas, on accepte aussi des élèves qui ne sont pas destinés à l'état monastique. Lorsqu'ils sont assez nombreux et que l'organisation dı monastèrc le permet, les séculiers sont instruits dans des locaux séparés de ceux des oblats". (Les Moines et la Civilisation en Occident. Des invasions à Charlemagne, Paris, Arthaud, 1962, p. 317-8).

(419). - Paré, Brunet, Tremblay, op cit., p. 40.

(420). - Idem, ibidem, p. 40. 
"Ciências e letras, por seu próprio objetivo, tendiam a se secularizar, a obter sua legítima autonomia fora da "escola do serviço divino", que é por definição o mosteiro; e os reformadores religiosos dão testemunho à sua maneira a essa primeira "laicização" do saber, quando êles excluem como deslocados nas suas escolas claustrais artes liberais, poesia, direito, medicina. Cada um com seu ofício" (421).

As escolas externas, ressentindo-se das novas vicissitudes pelas quais pasam não só as escolas em particular, como a própria vida monástica em geral, irão se rarefazendo, cada vez mais, até conhecer a sua extinção: as escolas da ordem de Cluny são internas (422); na ordem de Cister foram interditadas as escolas externas, só havendo escolas para os monges (423); proibia-se aos monges frequientarem as escolas públicas (424); a

"reação contra as escolas, destruidoras da disciplina monástica, ia tão longe, entre certos reformadores, que êles tinham mesmo se oposto às escolas dos oblatos, no interior dos mosteiros" (425);

por tôda parte onde ainda havia escolas externas dá-se a transferência das mesmas para as autoridades seculares (426); na primeira metade do século XII sòmente duas escolas externas continuavam a existir: a da abadia de São Vicente de Metz e a da abadia de Saint-Trond (427); por fim, completando a evolução, a Igreja irá interditar o ensino externo nas escolas monásticas (428). Dessa forma, as escolas externas ou públicas dos mosteiros que conheceram o seu apogeu entre os séculos IX-XI - época de economia eminentemente agrária, dominada por uma sociedade caracterìsticamente feudal e, pedagògicamente, beneditina, por excelência — não estiveram em condições de adaptar-se às novas necessidades inerentes a um nôvo mundo que, econômica,

(421). - Idem, ibidem, p. 40.

(422). - Idem, ibidem, p. 41 .

(423). - Idem, ibidem, p. 41.

(424). - Idem, ibidem, p. 43.

(425). - Idem, ibidem, p. 43.

(426) . - "A Lobbes, par exemple, vers 1134, l'abbé Leonius, venu d'Anchin, sous l'influence des idées de Cluny, enleva aux moines pour la confier à un chanoine, l'école de Saint-Ursmer qui avait fait la gloire de l'abbaye, et cela parce qu'il regardait la tenue des écoles comme contraire à la discipline monastique. Même transfert à Saint-Martin-en-Val et à Châteaudun, qui passent sous le rayonnement de l'école épiscopale de Chartres". (Idem, ibidem, p. 44). (427). - Idem, ibidem, p. 42, in nota.

(428). - Idem, ibidem, p. 44. 
social e culturalmente, vinha sendo elaborado pelo renascimento urbano e pelo renascimento cultural do século XII. E assim, por proibição, por transferência e, finalmente, por supressão acabaram desaparecendo as escolas externas dos mosteiros.

"Decididamente saimos do mosteiro" (429).

Enquanto isso, Portugal, decididamente, entrava no mosteiro. Em $1269 \mathrm{Fr}$. Estêvão Martins, abade de Alcobaça, fundava uma escola externa: foi a primeira escola externa ou pública que se instalou em Portugal (430). Manifestava-se com ela o arcaismo pedagógico português, em tôda a sua plenitude: surgia a referida escola, quando já desde o século XIl as escolas monásticas européias vinham perdendo o contacto com os tempos novos (431); não mais eram freqüentadas, pois a jovens geraçōes, as classes novas da sociedade não mais encontravam razão para frequentá-las (432) e a cultura - artes liberais, poesia, direito, medicina - nelas se achava deslocada (433); quando passou a se tornar impossível atribuir a essas escolas monásticas qualquer papel importante nos organismos do ensino (434); quando enfim, citando, novamente, Halphen, as escolas seculares é que se tornaram as verdadeiras escolas públicas e, dentre elas, as escolas catedrais ou episcopais foram as únicas que logo passaram a ser levadas em conta (435). E surgia ainda quando

"já as Universidades de Paris, Bolonha, Montpellier, Toulouse e outras tinham atrás de si uma brilhante história" (436).

\section{(Continua) .}

(429). - Idem, ibidem, p. 21.

(430). - Cf. Fr. Manuel dos Santos, op. cit., p. 102; Joaquim de Carvalho, op. cit., in "História de Portugal", Ed. Monumental, v. II, p. 600; Saraiva, op. cit., v. I, p. 88.

(431). - Paré, Brunet, Tremblay, op. cit., p. 39.

(432). - Idem, ibidem, p. 39.

(433). - Idem, ibidem, p. 40.

(434). - Idem, ibidem, p. 42.

(435). - Les Universités au XIIle siècle, loc. cit., p. 40.

(436). - Saraiva, op. cit., v. I, p. 88. 